\title{
Correction to: Channel-mediated astrocytic glutamate modulates hippocampal synaptic plasticity by activating postsynaptic NMDA receptors
}

\author{
Hyungju Park ${ }^{1 \dagger}$, Kyung-Seok Han ${ }^{1,2+}$, Jinsoo Seo ${ }^{3 \dagger}$, Jaekwang Lee ${ }^{1 \dagger}$, Shashank M. Dravid ${ }^{4}$, Junsung Woo ${ }^{1,2}$, \\ Heejung Chun', Sukhee Cho ${ }^{3}$, Jin Young Bae ${ }^{5}$, Heeyoung An ${ }^{1,6}$, Woohyun Koh ${ }^{1,2}$, Bo-Eun Yoon ${ }^{1,7}$, \\ Rolando Berlinguer-Palmini ${ }^{8}$, Guido Mannaioni ${ }^{9}$, Stephen F. Traynelis ${ }^{10}$, Yong Chul Bae ${ }^{5}$, Se-Young Choi ${ }^{3 *}$ and \\ C. Justin Lee ${ }^{1,2,6^{*}}$
}

\section{Correction to: Mol Brain (2015) 8:7} https://doi.org/10.1186/s13041-015-0097-y

Following publication of the original article [1], the authors would like to correct incomplete presentation of affilition 6. The corrected and complete presentation of affiliation 6 is:

${ }^{6}$ KU-KIST Graduate School of Converging Science and Technology, Korea University, 145 Anam-ro, Seongbukgu, Seoul, 02841, Korea.

The affiliation list has been updated in this Correction article and the original article [1] has been corrected.

\section{Author details}

${ }^{1}$ Center for Neural Science, Korea Institute of Science and Technology (KIST), Seoul, Korea. ${ }^{2}$ Neuroscience Program, University of Science and Technology (UST), Daejeon, Korea. ${ }^{3}$ Department of Physiology and Dental Research Institute, Seoul National University School of Dentistry, Seoul, Korea. ${ }^{4}$ Department

\footnotetext{
The original article can be found online at https://doi.org/10.1186/s13041015-0097-y.
}

\footnotetext{
*Correspondence: sychoi@snu.ac.kr; cjl@kist.re.kr

${ }^{\dagger}$ Hyungju Park, Kyung-Seok Han, Jinsoo Seo, Jaekwang Lee are equal contributors

${ }^{1}$ Center for Neural Science, Korea Institute of Science and Technology (KIST), Seoul, Korea

${ }^{3}$ Department of Physiology and Dental Research Institute, Seoul National University School of Dentistry, Seoul, Korea

Full list of author information is available at the end of the article
}

of Pharmacology, Creighton University, Omaha, NE, USA. ${ }^{5}$ Department of Oral Anatomy and Neurobiology, School of Dentistry, Kyungpook National University, Daegu, Korea. ${ }^{6} \mathrm{KU}-\mathrm{KIST}$ Graduate School of Converging Science and Technology, Korea University, 145 Anam-ro, Seongbuk-gu, Seoul 02841, Korea. ${ }^{7}$ Department of Nanobiomedical Science, Dankook University, Cheonan, Korea. ${ }^{8}$ School of Electrical and Electronic Engineering, Institute of Neuroscience, Newcastle University, Newcastle upon Tyne, UK. ${ }^{9}$ Department of Pharmacology, University of Florence, Florence, Italy. ${ }^{10}$ Department of Pharmacology, Emory University, Atlanta, GA, USA.

Published online: 29 June 2021

\section{Reference}

1. Park H, Han KS, Seo J, Lee J, Dravid SM, Woo J, Chun H, Cho S, Bae JY, An H, Koh W, Yoon B-E, Berlinguer-Palmini R, Mannaioni G, Traynelis SF, Bae Y, Choi S-Y, Lee CJ. Channel-mediated astrocytic glutamate modulates hippocampal synaptic plasticity by activating postsynaptic NMDA receptors. Mol Brain. 2015;8:7. https://doi.org/10.1186/s13041-015-0097-y.

\section{Publisher's Note}

Springer Nature remains neutral with regard to jurisdictional claims in published maps and institutional affiliations.

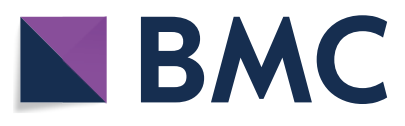

(c) The Author(s) 2021. This article is licensed under a Creative Commons Attribution 4.0 International License, which permits use, sharing, adaptation, distribution and reproduction in any medium or format, as long as you give appropriate credit to the original author(s) and the source, provide a link to the Creative Commons licence, and indicate if changes were made. The images or other third party material in this article are included in the article's Creative Commons licence, unless indicated otherwise in a credit line to the material. If material is not included in the article's Creative Commons licence and your intended use is not permitted by statutory regulation or exceeds the permitted use, you will need to obtain permission directly from the copyright holder. To view a copy of this licence, visit http://creativecommons.org/licenses/by/4.0/. The Creative Commons Public Domain Dedication waiver (http://creativecommons.org/publicdomain/zero/1.0/) applies to the data made available in this article, unless otherwise stated in a credit line to the data. 